\title{
Duodenum inclusion in alimentary transit for preventing or correcting nutritional deficiencies resulting from Roux-en-y gastric bypass in obesity treatment
}

\author{
Inclusão do duodeno no trânsito alimentar para prevenção ou correção de \\ deficiências nutricionais resultantes da derivação gástrica em y de Roux no \\ tratamento da obesidade
}

\author{
Reginaldo Ceneviva, ECBC-SP1
}

\begin{abstract}
A B S T R A C T
Nutritional and metabolic complications can develop after Roux-en-Y gastric bypass (RYGB) when there is an exaggerated response to the anatomical and functional changes or when there is inadequate nutritional supplementation. Severe malnutrition is rare, but deficiencies of vitamin B12, iron, calcium and thiamin, metabolic bone disease and gallstones are common after RYGB. Shortage of vitamin $B 12$, iron, calcium and also cholelithiasis are caused at least partially by excluding the duodenum and proximal jejunum from food transit. We designed a new procedure, with the maintenance of the duodenum and proximal jejunum in the gastrointestinal transit through interposition of jejunal loop, as a primary operation to prevent such deficiencies or as corrective surgery for severe malnutrition after RYGB with failure in responding to conservative treatment.
\end{abstract}

Keywords: Obesity, Morbid. Gastric Bypass. Anastomosis, Roux-en-Y. Malnutrition. Second-Look Surgery.

\section{INTRODUCTION}

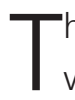
he Roux-en-Y gastric bypass (RYGB) is the most universally accepted technique for the surgical treatment of morbid obesity, with significant weight loss and frequent resolution of comorbidities in most patients.

The anatomical changes that are imposed by RYGB lead to dramatic reduction in the amount of nutrients available to patients. Nutritional and metabolic complications can develop when there is an exaggerated response to the anatomical and functional changes or when there is inadequate nutritional supplementation.

In RYGB the stomach volume is reduced; the surgeon creates a proximal gastric pouch with a capacity of 30 to $50 \mathrm{ml}$, anastomosed to a 70 to $100 \mathrm{~cm}$ jejunal loop, with transit reconstruction in a Roux-en-Y fashion with a jejunojejunostomy $50-70 \mathrm{~cm}$ distal to the angle of Treitz. The exclusion of the distal stomach, duodenum and proximal jejunum causes a marked reduction in the absorptive capacity of nutrients, electrolytes and bile salts $^{1}$ and may also hamper the entero-hepatic circulation of bile salts.

Complications like severe malnutrition $(4.7 \%)^{2}$, hypoalbuminemia $(5.3 \%)^{3}$, malabsorption of fats, fat-sol- uble vitamins and folate deficiency are uncommon; deficiency of Vitamin B12 (over 30\%) ${ }^{1}$, iron (20 to 49\%) ${ }^{1}$, Calcium $(16.7 \%)^{4}$ and thiamine, metabolic bone disease and cholelithiasis $(50 \%)^{1}$ are common after RYGB, though. The pathophysiology of these deficiencies in RYGB is related to reduced nutrient intake, decreased acidity, pepsin and intrinsic factor due to the stomach reduction and the exclusion of the stomach acid medium and of the absorptive surface of the duodenum and proximal jejunum.

Of these aforementioned RYGB-related deficiencies, the ones of B12 vitamin, iron and calcium, and also cholelithiasis, are caused, at least in part, by the duodenum and proximal jejunum exclusion.

On the other hand, there are studies that show excellent results in the treatment of serious nutritional deficiencies after extensive gastrectomy by converting the Billroth II reconstruction to a Henley, with reintroduction of the duodenum in the food transit through the interposition of a jejunal loop between the gastric stump and the duodenum ${ }^{5}$.

The interest in preventing or minimizing such postoperative complications justifies the attempt to modify the RYGB technique by maintaining the duodenum and proximal jejunum in the food transit.

1. Departamento de Cirurgia e Anatomia da Faculdade de Medicina de Ribeirão Preto da Universidade de São Paulo, Ribeirão Preto, SP, Brasil. 


\section{SURGICAL PROCEDURE}

The surgical procedure is done according to the technique schematics devised by the author's graphics (Figures 1 and 2).

The primary operation follows the technical steps of RYGB (Figure 1a) except for the reconstruction of the food transit: after gastrojejunostomy, the jejunal loop brought to the supramesocolic area and sectioned at approximately 25 to $30 \mathrm{~cm}$ from the anastomosis (Figure $1 \mathrm{~b}$ ) is latero-laterally anastomosed to the second portion of the duodenum, being complemented with the inframesocolic, termino-terminal, or preferably latero-lateral, jejunojejunal anastomosis (Figure 1c).

The 20 to $30 \mathrm{~cm}$ jejunal loop interposed between the stomach and duodenum is as effective as Roux-en-Y bypass to promote the reduction of enterogastric reflux ${ }^{6}$.

The inclusion of the duodenum in the food transit can also be used as a corrective surgery in patients with severe protein-calorie malnutrition unsolved by ex-

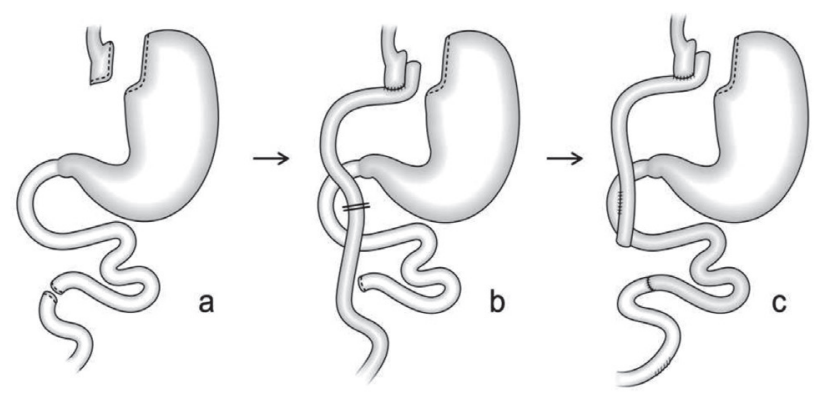

Figure 1. Roux-en-Y gastric bypass modified by the inclusion of the duodenum and proximal jejunum in the food transit as the primary surgery. a- making of the gastric pouch and section of the jejunum $70 \mathrm{~cm}$ distal to the angle of Treitz; b- gastrojejunal anastomosis and section of the alimentary loop 20 to $30 \mathrm{~cm}$ distal to the gastrojejunostomy; c- transit reconstruction with two anastomoses, one latero-lateral jejunoduodenostomy and one termino-terminal jejunojejunostomy. haustive conservative treatment attempts, and can be achieved through two techniques (Figure 2).

The first technique involves two sections and two anastomoses (Figures $2 \mathrm{~b}$ and $2 \mathrm{c}$ ) and the second, only one section and one anastomosis (Figures $2 \mathrm{~b} 1$ and 2c1), but the former, with a short interposed jejunal loop, should be the choice when the RYGB original alimentary loop (Figure 2a) is long, favoring angulation.

The results of clinical evolution and nutritional and metabolic aspects of patients undergoing this technique as a primary or corrective surgery for severe protein-calorie malnutrition with conservative treatment failure were satisfactory and, in due course, will be published.

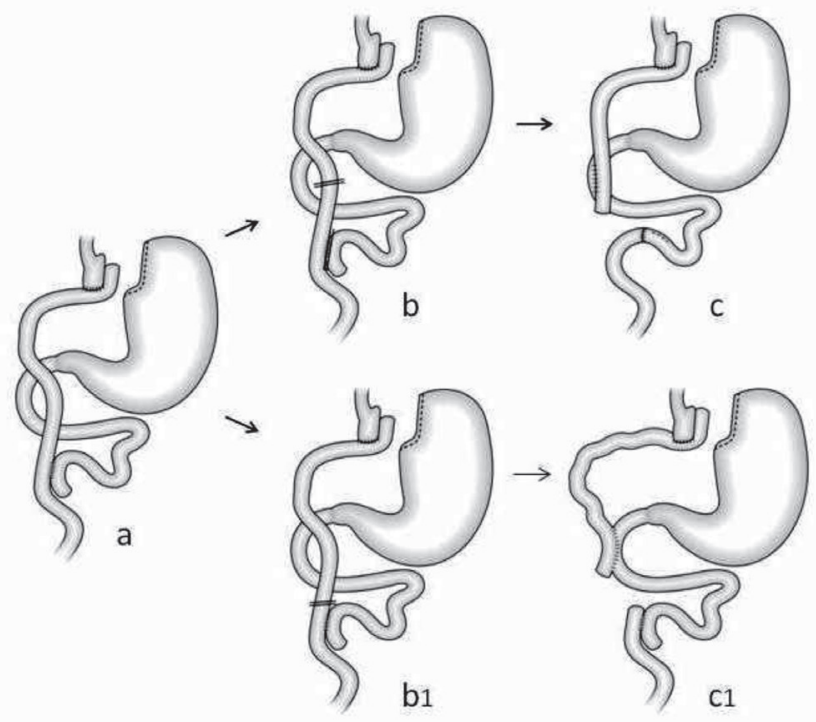

Figure 2. Inclusion of the duodenum and proximal jejunum in the food transit with interposition of jejunal loop as a corrective surgery after Roux-en-Y gastric bypass. a- Roux-en-Y gastric bypass; $b$-Stapler section of the alimentary loop 20 to $30 \mathrm{~cm}$ distal to the gastrojejunostomy and of the biliopancreatic loop next to the jejunojejunal anastomosis; c- transit reconstruction with jejunoduodenal and jejunojejunal anastomoses; b1-Stapler section of the alimentary loop next to the jejunojejunal anastomosis; c1- transit reconstruction with jejunoduodenal anastomosis.

\section{R E S U M O}

Complicações nutricionais e metabólicas podem se desenvolver após a derivação gástrica em Y de Roux (DGYR) quando há uma resposta exagerada às mudanças anatômicas e funcionais ou quando há suplementação nutricional inadequada. A desnutrição grave é rara, mas deficiências de vitamina B12, ferro, cálcio e tiamina, doença óssea metabólica e cálculos biliares são comuns após a DGYR. Dessas deficiências mencionadas, a de vitamina B12, de ferro, de cálcio e também a colelitíase, são causadas, ao menos parcialmente, pela exclusão do duodeno e jejuno proximal. Um novo procedimento com a manutenção do duodeno e do jejuno proximal no trânsito gastrointestinal, mediante interposição de alça jejunal, foi idealizado como operação primária para prevenir essas deficiências ou como cirurgia corretiva de desnutrição grave após DGYR com falha na resposta a exaustivas tentativas de tratamento conservador.

Descritores: Obesidade Mórbida. Derivação Gástrica. Anastomose em-Y de Roux. Desnutrição. Cirurgia de Revisão. 


\section{REFERENCES}

1. Malinowski SS. Nutritional and metabolic complications of bariatric surgery. Am J Med Sci. 2006;331(4):219-25.

2. Faintuch J, Matsuda M, Cruz ME, Silva MM, Teivelis $M$, Garrido $A B$ Jr, et al. Severe protein-calorie malnutrition after bariatric procedures. Obes Surg. 2004;14(2):175-81.

3. Dalcanale L, Oliveira CP, Faintuch J, Nogueira MA, Rondó P, Lima VM, et al. Long-term nutritional outcome after gastric bypass. Obes Surg. 2010;20(2):181-7.

4. Bavaresco M, Paganini S, Lima TP, Salgado W Jr, Ceneviva R, Dos Santos JE, et al. Nutritional course of patients submitted to bariatric surgery. Obes Surg. 2010;20(6):716-21.
5. Ramus NI, Williamson RC, Johnston D. The use of jejunal interposition for intractable symptoms complicating peptic ulcer surgery. Br J Surg. 1982;69(5):265-8.

6. Sousa JE, Troncon LE, Andrade JI, Ceneviva R. Comparison between Henley jejunal interposition and Rou$\mathrm{X}$-en-Y anastomosis as concerns enterogastric biliary reflux levels. Ann Surg. 1988;208(5):597-600.

Received in: 07/11/2015

Accepted for publication: 08/03/2016

Conflict of interest: none.

Source of funding: none.

Mailing address:

Reginaldo Ceneviva

E-Mail: rceneviv@gmail.com 